2013

\title{
The Impact of Influence Tactics in Information System Development Projects: A Control-Loss Perspective
}

Ravi Narayanaswamy

Varun Grover

Raymond M. Henry

Cleveland State University, r.henry22@csuohio.edu

Follow this and additional works at: https://engagedscholarship.csuohio.edu/bus_facpub

Part of the Technology and Innovation Commons

How does access to this work benefit you? Let us know!

Publisher's Statement

This is an Author's Accepted Manuscript of an article published Journal of Management Information Systems, 2013, available online: http://www.tandfonline.com.

Original Published Citation

Narayanaswamy, R., Grover, V., Henry, R. M. (2013). The Impact of Influence Tactics in Information System Development Projects: A Control-Loss Perspective. Journal of Management Information Systems, 30(1), pp. 191-226.

This Article is brought to you for free and open access by the Monte Ahuja College of Business at EngagedScholarship@CSU. It has been accepted for inclusion in Business Faculty Publications by an authorized administrator of EngagedScholarship@CSU. For more information, please contact library.es@csuohio.edu. 


\title{
The Impact of Influence Tactics in Information System Development Projects: A Control-Loss Perspective
}

\author{
RAVI NARAYANASWAMY, VARUN GROVER, AND \\ RAYMOND M. HENRY
}

RAVI NARAYANASWAMY is an assistant professor of management information systems in the Department of Management at University of South Carolina-Aiken. He holds a Ph.D. in information systems from the College of Business \& Behavioral Sciences at Clemson University. His research interests focus on issues pertaining to organization control, team leadership, managerial influence behavior, and governance in information systems development. His research papers have appeared or are forthcoming in the Journal of the Association for Information Systems, Database, among other journals, as well as in the proceedings of national and international conferences.

Varun Grover is the William S. Lee (Duke Energy) Distinguished Professor of Information Systems at Clemson University. He holds a Ph.D. in management information systems from University of Pittsburgh. He is currently working in the areas of individual, organizational, and interorganizational IT effects - particularly those pertaining to IT value. He has published extensively in the information systems field, with over 200 publications in major refereed journals. Ten recent articles have ranked him among the top four researchers based on the number of publications in the top information systems journals as well as citation impact (h-index). Dr. Grover is senior editor of MISQ Executive and senior editor (emeritus) of MIS Quarterly, Journal of the Association for Information Systems, and Database. His Business Process Transformation is his third in the Advances in Management Information Systems series (with M. Lynne Markus, M.E. Sharpe, 2008). He is recipient of numerous awards from the University of South Carolina, Clemson, Association for Information Systems, Decision Sciences Institute, Anbar, PriceWaterhouse, and others for his research and teaching, and is a Fellow of the Association for Information Systems.

RAYMOND M. HenRy is an associate professor of computer and information science in the Monte Ahuja College of Business at Cleveland State University. He received his Ph.D. in information systems from the University of Pittsburgh. His research has been published in premier journals, including Information Systems Research, Journal of Management Information Systems, Communications of the ACM, Journal of the Association for Information Systems, and Journal of Operations Management. He has also presented his work at numerous national and international conferences.

AвSTRACT: Information systems development (ISD) projects are prone to high levels of failure. One of the major reasons attributed to these failures is the inability to harmonize values held by a diverse set of participants in an environment that is characterized by uncertainty due to changing requirements. In this paper, we focus on a relational 
approach to achieve congruence between a project manager and a team member with respect to influence tactics. Constructs of perceptual congruence and communication congruence that reflect a level of agreement and degree of shared understanding between the project manager and team members are described. A congruence model is constructed and tied to an intermediate outcome variable of control loss. One hundred and thirteen dyadic pairs of project managers and team members are surveyed in order to test the model. The results indicate that having strong relational equity and common understanding can minimize control loss. It is important to consider the perspectives of both the project manager and a team member while formulating and assessing monitoring strategies to promote the success of an ISD project. Especially, encouraging team members to discuss disagreements constructively can motivate them to perform better and keep things under control. Finally, it is critical to address the performance problems as they occur rather than wait until the completion of the project.

KEY WORDS AND PHRASES: developer relationships, development project, influence tactics, information systems development, leadership exchange, project management, project manager, shared understanding, teams.

SuCCESSFUl MANAGEMENT OF INFORMATION SYSTEMS DEVELOPMENT (ISD) projects is a challenge for organizations. Recent reports indicate that ISD projects are increasingly getting out of control, which can have dire consequences on organizational performance [13]. Reasons contributing to project failure include the failure to obtain cooperation among multiple stakeholders with partially congruent objectives [33, 43 ] and elusive performance measures used to monitor project progress contribute to project failure [2].

ISD projects involve complex, nonroutine, knowledge-intensive tasks and teams with diverse knowledge and skills [27]. Moreover, ISD projects face a high degree of requirement volatility and technological uncertainty, which enforces the need to continuously adapt to a changing environment [62]. A key challenge for a project manager is to ensure that all the member goals are congruent and are aligned with the project objectives [34]. The leadership literature suggests that environments similar to ISD projects can be effectively managed by creating a balance between management and leadership [73]. In particular, it suggests developing high-quality relationship, building on congruent values between the managers and those managed [55, 78].

This study applies leader-member exchange (LMX) and the flexible leadership model (FLM) to explore effective ways to manage ISD projects. LMX theorists focus on the quality of the exchange relationship and suggests the importance of building a high-quality exchange relationship through harmonization of values held between the leader and the subordinate [17] to enhance organizational and team performance [18, 58]. The FLM focuses on integrating leadership and management roles rather than holding them mutually exclusive. It contends that a balance between leadership and management is important to improve organizational effectiveness and that performance can be improved through effective coordination and motivation [73]. The emphasis is on 
how managers enact both as a leader and a manager. The leadership literature suggests that managers use influence tactics, for example, consultation, inspirational appeals, exchange, legitimation, and pressure tactics, to manage team member behaviors and attitudes $[11,71,72,76]$. The extent to which these tactics promote quality exchange and flexible leadership has not been explored in ISD projects.

This study integrates these various perspectives to develop a congruence framework in order to systematically analyze harmonization between project manager and team member values. As aforementioned, ISD projects are complex, nonroutine, and require those involved to continuously adapt to the rapidly changing project environment. Developing congruent values can reduce the opportunity for self-seeking or opportunistic behavior. For instance, team members with congruent values tend to expend extra time and effort, engage in extra-role behaviors, and help fellow team members with important tasks $[12,60]$. Two types of congruence reflecting coordination (communicational congruence) and motivation (perceptual congruence) with respect to influence tactics are examined.

On the outcome side, prior research typically measures project performance using metrics related to time, cost, and quality [54]. These metrics are typically evaluated at the completion of the project. A project is considered to be successful if there are no time or cost overruns and it meets expectations. Recent studies indicate that many problems occur throughout project development that if addressed would improve project success $[40,41]$. Within practice, project managers are expected to be proactive in identifying and fixing things that can go out of control during the project in order to avoid huge sunk costs [22]. In this study we develop an intermediate outcome variable - control loss. This measure assesses project progress along three dimensions - people, processes, and resources - that can be evaluated while the project is being developed.

In the management domain, control loss has been used to capture errors, both intentional and unintentional, that occur between superiors and subordinates in multihierarchical organizations $[9,10]$. For instance, as orders flow through multiple channels, part of the original intentions gets lost, which in turn affect organizational performance [67]. Furthermore, control loss has been used in various contexts to capture intermediary slippages with respect to people, processes, and resources in dyadic relationships [16, 30]. This study not only adopts the control loss concept but also embeds it into an ISD context by developing an instrument specific to ISD projects.

Specifically, the following research questions are addressed:

RQ1: How does communicational congruence between project managers and team members on the use of influence tactics affect control loss?

RQ2: How does perceptual congruence between project managers and team members on the appropriateness of influence tactics affect control loss?

The remainder of this paper proceeds as follows. The next section outlines the key points from LMX and the FLM to develop a congruence framework. For the dependent variable, research on project performance metrics is summarized and control loss is 
presented as an alternative intermediate outcome variable. We then describe the survey methodology used to test the model. Finally, data analysis, findings, and implications for research and practice are discussed.

\section{Theoretical Development}

THE THEORETICAL BASIS FOR OUR MODEL draws from the leadership literature. This section highlights the concepts of LMX and the FLM that form the basis for a congruence framework. Following this, we explain why extant project performance metrics would be enriched by the development of an intermediate outcome variable.

\section{Leader-Member Exchange, Flexible Leadership, and Congruence Framework}

One of the key strengths of LMX is that it encompasses concepts from both transactional and transformation leadership [17]. The exchange between the leader and member begins as transactional but evolves into transformational. In addition, the exchange is not limited to material exchange but can include social and psychological exchanges such as mutual esteem, trust, and support [17]. LMX relationships are described as "(a) a system of components and their relationships, (b) involving both members of a dyad, (c) interdependent patterns of behavior, (d) sharing mutual outcome instrumentalities and, (e) producing conceptions of environments, cause maps, and values" [55 p. 580]. The central premise of LMX theory is the reciprocal relationship held between the leader and the team [78]. In the leader-team member dyad, each party has expectations about how he or she can benefit from the other party and what must be given in return. Those who feel that they are benefiting from a relationship will try to reciprocate by fulfilling the other party's expectations [31, 32]. LMX represents a set of social approaches rather than a particular leadership style. Leadership is viewed as social problem solving, whereby leaders are responsible for (1) diagnosing any problems that could potentially impede team and organizational goal attainment, (2) generating and planning appropriate solutions, and (3) implementing solutions within typically complex social domains [17]. High LMX relationships have been found to increase positive discretionary behaviors such as helping coworkers and willingness to share expertise in uncertain and complex situations that are typified in ISD contexts [37, 60].

The main emphasis of the LMX research is on the relationship between the leader and members. It is important to consider the how the leader places his or her request to the members. Prior research suggests influence tactics as a key determinant to LMX [17, 69]. Leaders use various influence tactics, including, for example, consultation, inspirational appeals, exchange, legitimation, and pressure tactics to shape subordinates attitudes and behaviors in response to requests $[11,71,72,76]$. Descriptions of these tactics are presented in Table 1.

Prior studies note that usually a combination of tactics rather than a single tactic is used to achieve successful outcomes [11]. An influence tactic implicitly sends a signal 
Table 1. Overview of Influence Tactics

\begin{tabular}{|c|c|}
\hline $\begin{array}{l}\text { Influence } \\
\text { behavior }\end{array}$ & Description \\
\hline $\begin{array}{l}\text { Rational } \\
\text { persuasion }\end{array}$ & $\begin{array}{l}\text { The agent uses logical arguments and factual evidence to persuade } \\
\text { the target that a proposal or request is viable and likely to result in } \\
\text { the attainment of task objectives. }\end{array}$ \\
\hline Legitimating & $\begin{array}{l}\text { The agent seeks to establish the legitimacy of a request by claiming } \\
\text { the authority to make it or verifying that it is consistent with the } \\
\text { organizational rules, procedures, and policies. }\end{array}$ \\
\hline Pressure & $\begin{array}{l}\text { The agent uses demands, threats, frequent checking, or persistent } \\
\text { reminders to influence the target to do what he or she wants. }\end{array}$ \\
\hline Consultation & $\begin{array}{l}\text { The agent seeks target participation in planning a strategy, activity, or } \\
\text { change for which target support and assistance are desired, or the } \\
\text { agent is willing to modify a proposal to deal with target concerns } \\
\text { and suggestions. }\end{array}$ \\
\hline Collaboration & The agent offers assistance to the target for completing a task. \\
\hline Coalition & $\begin{array}{l}\text { The agent seeks the aid of others to persuade the target to do } \\
\text { something or uses the support of others as a reason for the target } \\
\text { to agree also. }\end{array}$ \\
\hline Ingratiation & $\begin{array}{l}\text { The agent uses praise, flattery, friendliness, or helpful behavior to put } \\
\text { the target in a good mood or to think favorably of the agent when he } \\
\text { or she asks for something. }\end{array}$ \\
\hline
\end{tabular}

Source: [2].

to members regarding their relative standing with the leader [60]. For instance, the influence tactics literature reveals that

a tactic is more likely to be successful if the target (member) perceives it to be a socially acceptable form of influence behavior, if the agent (leader) has sufficient position and personal power to use the tactic, if the tactic has the capability to affect the target's attitudes about the desirability of the request, if the tactic is used in a skillful way, and if it is used for a request that is legitimate and consistent with the target's values and needs. [74, p. 526, emphasis added]

Thus, in order to obtain successful outcomes, there should be congruence between the leader and the member regarding the chosen influence tactic. This emphasizes the centroid concept of LMX, which contends that effective leadership processes occur when leaders and followers are able to develop mature leadership relationships (partnerships) [17]. It also raises an important issue about the nature of congruence that must be considered between the leader and the member to produce positive outcomes.

The FLM suggests that leaders should adopt a flexible leadership style and have the social perceptiveness and behavioral flexibility to ascertain changing needs in order to establish and maintain values congruent with the team [79]. It contends that a balance between management and leadership must be maintained in order to promote organizational effectiveness. The leader and manager roles are viewed to be complementary rather than mutually exclusive. It suggests that how the role (leader 
or manager) is enacted is as important as the role itself. Accordingly, the role assumed is not defined by a specific set of behaviors but rather by generic responses that will vary in different problem situations. The FLM considers three determinants of performance: (1) efficiency and process reliability, (2) human resources and relations, and (3) adaptation and innovation [73]. The management role focuses on improving efficiency and process reliability. This role is enacted by establishing effective coordination mechanisms to clarify roles and task objectives, monitoring operations, and resolving any goal ambiguity. The leadership role focuses on improving human resources and relations. This role is enacted by enhancing subordinate motivation to foster collective learning, encouraging creative thinking, and articulating an inspiring vision. Effective adaptation and innovation involves both coordination and motivation, thus requiring a balance between management and leadership. From a broader perspective, effective coordination aims at helping team members understand their role in the task, how they are expected to complete the task, and the particular types of information that has to be delivered [4]. Motivation emphasizes the actions taken by leaders to encourage the team to perform the task. In other words, the leader should know how to monitor team members, when to step in and help the team, and when to change his or her behavior in response to the needs of the team $[4,78]$.

The three determinants of performance presented by the FLM can be extended to ISD project performance. An ISD project is considered a success if it is completed within the set time, set cost, and meets the original expectations [6]. Efficiency means low cost, which is important for project success. Process reliability is important to avoid mistakes and ensure the set expectations are met. Human resources and relations are especially important because ISD projects require highly motivated and skilled team members [19]. Adaptation and innovation are important because ISD projects have to cope with the unpredictable changes in technology [43]. Thus, similar to the propositions of the FLM, three determinants can be improved through a balance of management and leadership, which are enacted through effective coordination and motivation. These notions are captured using two types of congruence-communicational congruence and perceptual congruence. Communicational congruence captures the coordination aspect and is defined as the degree of shared understanding regarding the chosen influence tactics. Perceptual congruence captures the motivational aspect and is defined as the level of agreement regarding the appropriateness of the chosen influence tactics. These definitions are consistent with extant research in the LMX domain $[51,66]$.

\section{Project Performance Measures}

Most of the prior ISD research uses conventional measures of success that evaluate a project as being successful when it is completed within or near an estimated schedule and budget, and produces an acceptable level of performance [1, 2]. ISD project performance is generally defined in terms of time, budget, and scope. Recent research uses multiple dimensions such as task outcomes, psychological outcomes, and organizational outcomes to measure project success [3]. 
A common element among the extant dimensions of success is that they are measured ex post (i.e., after completion of the project). While informative, post hoc evaluation has limited implications for diagnostics, especially given the huge sunk costs associated with failed ISD projects [15]. ISD is done in several phases: requirement analysis, design, development, testing, and implementation [50]. Recent studies indicate that ISD projects face numerous problems throughout development that, if addressed, can enhance the chances of project success [40, 41]. For instance, gold plating (i.e., including unnecessary features) is a common issue that occurs during the design phase [40]. Senior management often urge project managers to proactively control and assess things that might go wrong from all points of view [22]. From a performance viewpoint, it is more beneficial to understand what caused the delays in schedule, budget, and time rather than simply saying that the project had cost and time overruns. Inasmuch, identifying problems occurring while the project is being developed can give managers an opportunity to rectify issues and to plan future actions to ensure the project remains on track.

Several intermediate measures such as earned value analysis, schedule variance, and performance risk have been discussed in both the practitioner and academic literature (e.g., $[42,50])$; however, the ethereal nature of ISD projects often inhibits managers from applying sophisticated estimation techniques, thus making the accuracy of intermediate time/cost/quality measures questionable [39, 68]. All these measures mainly focus on technical or developmental processes, while many of the intermediary problems in ISD projects are primarily related to people, processes, and resources (e.g., [40, 41]).

Table 2 summarizes problems that contributed to the failure of 99 projects that were examined in prior research studies [40, 41]. It can be seen that issues related to goal conflicts, misunderstandings regarding responsibilities, and resource unavailability frequently contribute to project failure. More importantly, these studies note that rectifying the problems that occur while the project is being developed could have improved the chances of completing the project successfully. Accordingly, this study develops an intermediate outcome variable to assess project progress while the project is ongoing. We draw from research on control loss in the management domain to develop this intermediate outcome variable.

\section{Control Loss}

Control loss refers to slippages (deviation from the set objectives) in achieving the original intentions due to distortion in communicating expectations [67]. It has been used to capture coordination problems between supervisors and subordinates. Organizational control theorists found that introducing multihierarchies is an important aspect of organizational design, but they were not a panacea $[9,10,44]$. In some cases these structures actually decreased performance due to distortion in the transmission of information and authority that in turn decreased the quality of exchange relationship [67]. Errors, both intentional and unintentional, that occurred between a superior and a subordinate in a hierarchy have been shown to cause intermediary slippages such 
Table 2. Common Mistakes in ISD Projects

\begin{tabular}{|c|c|c|c|}
\hline Dimension & Mistake & Description & $\begin{array}{l}\text { Projects facing } \\
\text { the problem* } \\
\text { (percent) }\end{array}$ \\
\hline \multirow[t]{4}{*}{ People } & $\begin{array}{r}\text { Undermined } \\
\text { motivation }\end{array}$ & $\begin{array}{l}\text { Team members are not willing } \\
\text { to perform the task due to } \\
\text { unnecessary restrictions }\end{array}$ & 26 \\
\hline & Group cohesiveness & $\begin{array}{l}\text { Poor working relationships } \\
\text { among team members }\end{array}$ & 37 \\
\hline & Leadership & $\begin{array}{l}\text { Failure to take action to deal } \\
\text { with problematic employee }\end{array}$ & 37 \\
\hline & $\begin{array}{l}\text { Human resource } \\
\text { wastage }\end{array}$ & $\begin{array}{l}\text { Adding people to a late project, } \\
\text { taking away existing team } \\
\text { productivity }\end{array}$ & 39 \\
\hline \multirow[t]{3}{*}{ Process } & $\begin{array}{l}\text { Ineffective } \\
\text { governance } \\
\text { process }\end{array}$ & $\begin{array}{l}\text { Wasting time in approval and } \\
\text { budgeting processes }\end{array}$ & 51 \\
\hline & $\begin{array}{l}\text { Undermining team } \\
\text { capabilities }\end{array}$ & $\begin{array}{l}\text { Setting overly optimistic } \\
\text { schedules, failure to obtain } \\
\text { team consensus }\end{array}$ & 54 \\
\hline & $\begin{array}{l}\text { Insufficient risk } \\
\text { management }\end{array}$ & $\begin{array}{l}\text { Failure to proactively assess } \\
\text { and control things that might } \\
\text { go wrong }\end{array}$ & 47 \\
\hline Product & $\begin{array}{l}\text { Developer/user gold } \\
\text { plating }\end{array}$ & Including unnecessary features & 8 \\
\hline \multirow[t]{2}{*}{ Technology } & $\begin{array}{l}\text { Silver-bullet } \\
\text { syndrome }\end{array}$ & $\begin{array}{l}\text { Team attachment to single } \\
\text { technology even when they } \\
\text { know it is not working out }\end{array}$ & 4 \\
\hline & Knowledge/learning & $\begin{array}{l}\text { Switching or adopting } \\
\text { technology without } \\
\text { considering team expertise }\end{array}$ & 8 \\
\hline
\end{tabular}

as failure to act in a desired manner, which can lead to failure in achieving original goals. As orders flow through multiple channels, they can be misinterpreted and parts of the original messages lost [67].

LMX researchers have found that subordinates often failed to carry out the superior's intentions; in some cases they performed the task but failed to follow predefined procedures $[9,10]$. One underlying reason leading to control loss is the leader's failure to adapt his or her leadership behaviors to be consistent with the changing environment [5]. In addition, it has been observed that subordinates may follow prescribed behaviors even when these behaviors are inappropriate or that they fail to identify gaps in instructions, contributing to control loss [5]. Studies examining control loss from an organizational control perspective reveal goal conflicts, information asymmetry, lack 
of harmonization of values, resource misuse, and resource unavailability as potential causes for control loss [30, 45, 48].

A common agreement among all the above-mentioned studies is that (1) control loss is inherent in dyadic relationships; (2) as interdependence between the leader and the member increases, it presents more opportunity for control loss [30]; (3) control loss is cumulative, that is, when it is not addressed, control loss increases; and (4) control loss has adverse effects on final outcomes such as organizational performance [45]. Most of these findings have been based on simulations and theoretical assertions. This study develops a scale for the measurement of control loss within ISD that builds on the existing research to further our understanding of this construct and its application.

Conceptually, control loss is applicable to the ISD project context because ISD projects suffer from intermediary problems related to people, processes, and resources [40, 41]. The project manager and team member are highly interdependent; miscommunication in their relationship can have dire consequences on the project outcomes. In addition, common mistakes such as undermined motivation, ineffective governance processes, and leadership (see Table 2) are similar to those observed in multihierarchical organizations. ISD projects face high complexity and high uncertainty [42], which in turn can decrease the quality of the exchange relationship, especially if the right actions are not administered at the right time. Furthermore, ISD project orders in particular emanate and flow from multiple stakeholders [28, 35], which presents an opportunity for distortion in the transmission of authority and information.

In this study, control loss is defined as the extent to which people, processes, and resources are not progressing as expected (i.e., not under control). The people dimension focuses on issues such as the extent to which team members carry out tasks efficiently, aptly follow instructions, and perform at optimum levels. The process dimension addresses issues related to change control, the application of methodology, and other prescribed processes and the auditability standards used to maintain the quality of the technical and management process. The resource dimension focuses on issues related to resource availability, allocation, and control. These dimensions were identified based on the synthesis of published ISD project cases [25, 26, 35, 46, 64], case descriptions of the famous information technology (IT) project failures listed in Nelson [40, 41], and professional documents such as the Project Management Body of Knowledge (PMBOK) [50] and Information Technology Infrastructure Library (ITIL; www.itil-officialsite.com).

\section{Hypothesis Development}

THE UNDERLYING THESIS OF THIS RESEARCH is that developing congruent values between the project manager and team members will alleviate intermediary problems that occur while the project is being developed. In particular, it is argued that communicational and perceptual congruence between the project manager and team members with respect to influence tactics can reduce control loss. Communicational congruence refers to the degree of shared understanding regarding the chosen influence tactics. Perceptual congruence refers to the level of agreement between the project manager 


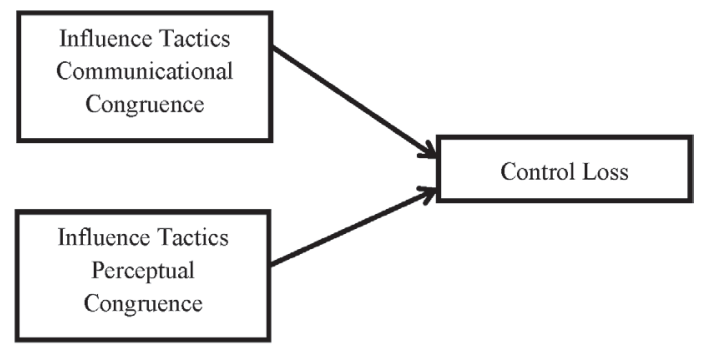

Figure 1. Research Model

and the team member(s) regarding the appropriateness of chosen influence tactics. The research model is shown in Figure 1.

\section{Influence Tactics, Communicational Congruence, and Control Loss}

Past leadership studies have noted that leader communication of enriched task information to the team results in high group effectiveness [36]. Similarly, research examining the leaders' influence on group emotion has demonstrated that team members are likely to display less negative emotional reactions if leaders provide clear team goals, clear specification of member roles, and unambiguous performance strategies [24]. In the team context, influence tactics help shape and direct team members' behavior in order to obtain a desired response for a specific request. Each influence tactic requires different skills to accomplish the task; for instance, consultation requires effective participation whereas rational persuasion needs logical documentation. If the project manager is using a tactic and the team member does not understand it, then the team member may not respond to the tactic in the way the project manager expects, resulting in control loss by reducing the ability of the project manager to manage the project. Thus, in order to act in a desired manner, both parties need a common understanding of the chosen influence tactic. Lack of congruence can lead to decreased process efficiency and reliability [71, 76].

Within the ISD context, previous research has noted capricious requirements as a key source of uncertainty in ISD projects [62]. ISD projects are subject to changing business needs or competitive pressure, which in turn introduce new demands during the development process [42]. As a result, both the project manager and team member need to make necessary adjustments to satisfy new demands. For instance, the project manager may revise the combination of influence tactics, which may require team members to acquire new skills to perform the tasks. If, however, the project manager and the team members lack shared understanding, then it may lead to undesired outcomes such as not meeting the objectives. The following excerpt from a real ISD project illustrates this notion:

Monday morning we [team] were given notice that something was due . . 3 P.M. Tuesday. Three of us stayed all night. I grabbed the output from the printer and 
ran to our meeting ... only to find out that yesterday afternoon our 3 P.M. meeting was indefinitely delayed. [46, p. 339]

In this case, it is clear that the team member continued to pursue the pressure tactic even when the tactic was no longer needed. As the project progressed, the tasks were being completed on time but other expectations such as quality participation were not satisfactorily met. In the end, the project was delayed due to redundancy and scope creep. This leads to our first hypothesis:

Hypothesis 1: Communicational congruence regarding influence tactics will be negatively associated with control loss.

\section{Influence Tactics, Perceptual Congruence, and Control Loss}

The leadership literature concludes that in the face of collective obstacles, a motivated team accepts more unforeseen challenges [65]. A leader's behavioral style conveys the subordinates' standing with the leader [76]. LMX researchers have observed instances of control loss when the leader fails to align the leadership style with the existing relationship [16]. Research has also demonstrated significant linkages among influence tactics and motivational processes [70]. Prior studies suggest that managers consider factors such as the nature of the relationship and team expertise when selecting an influence tactic [60]. For example, more consultation and less pressure are more appropriate for a team that is confident and competent than for one that is not. Using a wrong influence tactic may have a strong adverse effect such as demotivating the team.

In ISD projects, team members are considered to be knowledge workers with significant levels of expertise [27]. Accordingly, it is important for the project manager to choose a combination of tactics that are in line with the team's skills and competence. This is especially true in the ISD context where the requirements are highly volatile and team members must accommodate unforeseen challenges [62]. To illustrate, consider this scenario from a real ISD project:

The strict deadlines seemed impossible. . . . I [team member] was reluctant to fully integrate myself into the environment which was different to what we [team members] were used to. . . It was a school room attitude, with someone senior to me telling me to do as he says. [64, p. 365]

This excerpt clearly shows a disagreement between the project manager and team member regarding the influence tactic (pressure) leading to a lack of cooperation. In this case, the project was delayed and the project manager was removed from his role. This is consistent with previous research that asserts that when both the leaders' and teams' beliefs/values converge, there is better performance in highly complex situations [47]. Along the same lines, motivation losses were noted in episodes in which there were disagreements between the manager and the subordinate(s) regarding expectations [29, 55, 56, 57]. This leads to our second hypothesis: 
Hypothesis 2: Perceptual congruence regarding the influence tactic used will be negatively associated with control loss.

In sum, $\mathrm{H} 1$ deals with the degree of shared understanding of the tactic use while $\mathrm{H} 2$ deals with level of agreement about the appropriateness of the tactic.

\section{Research Methodology}

DATA FROM 113 ONGOING ISD PROJECTS WERE COLLECTED to test our research model. Because one of our objectives was to capture intermediary problems, only ongoing projects were considered. To ensure that significant activities had occurred, at least 20 percent and not more than 80 percent of the project's work needed to be completed at the time of this study, with at least one major deliverable completed. These criteria were chosen to ensure there was sufficient information for evaluating control loss. In addition, this would ensure that the project manager had sufficient information to choose and implement influence tactics and that the team members had enough time to realize the chosen tactics. A renowned research service provider MarketTools ${ }^{\circledR}$ was employed to assist with data collection. MarketTools ${ }^{\circledR}$ is a part of Zoomerang, which helps researchers host online surveys to the desired sample group. MarketTools ${ }^{\circledR}$ has a number of IT professionals in its sample frame.

Several check points were used to ensure the quality of the responses. The members of the database used to administer the survey were checked to confirm that the sample was representative of IT professionals with appropriate IT project management experience. The responses were closely monitored to verify the parameters (project name or code, project type) required to match the responses were complete and accurate.

Because another objective of this research was to measure congruence, a matchedpair survey approach was chosen. For each project, responses were obtained from both the project manager and a team member. The use of two respondents allows the multiple perspectives necessary to capture congruence and prevents any potential single-source bias. Both the project managers and the team members were asked to indicate the extent of use (communicational congruence), and the degree of appropriateness of the chosen tactics was evaluated by the team members. A total of 113 complete matched pairs from 109 organizations were used for analysis. The descriptive characteristics of the sample are listed in Tables 3 and 4.

The organizations contributing to the sample represented a broad range of industries, including software (30 percent), manufacturing ( 24 percent), and consulting (20 percent). Most of the projects were in the development phase (31 percent), thus indicating high involvement of the team members [26]. The sample represents internal ISD efforts with all the project phases done in-house. The project managers were highly experienced in IT project management ( 34 percent $>10$ years) and very knowledgeable about the project being managed $($ mean $=5.5, \mathrm{SD}$ [standard deviation] $=1.39)$. The team members also had good IT experience (43 percent $>6$ years) and were knowledgeable about the project they were involved in (mean $=5.3, \mathrm{SD}=1.42$ ). 
Table 3. Sample Characteristics

\begin{tabular}{lcc}
\hline & Average & $\begin{array}{c}\text { Standard } \\
\text { Deviation }\end{array}$ \\
\hline Number of employees & 10,287 & 26,551 \\
Number of IS employees & 1,000 & 3,500 \\
Team size (number of team members) & 7 & 5.5 \\
Project duration (months) & 12 & 15 \\
Project budget (dollar amount) & 485,000 & 898,000 \\
Project manager involvement (number of months) & 7.12 & 6.36 \\
Project manager IS experience (number of years) & 3.82 & 1.87 \\
Project manager tenure & 3.08 & 1.86 \\
Project manager knowledge of the project & 5.5 & 1.39 \\
Team member involvement (number of months) & 7.12 & 6.30 \\
Team member IS experience (number of years) & 3.33 & 1.86 \\
Project schedule completed (number of months) & 7.75 & 6.83 \\
Team member knowledge of the project & 5.3 & 1.42 \\
\hline
\end{tabular}

Table 4. Organizations by Industry

\begin{tabular}{lc}
\hline Industry type & $\begin{array}{c}\text { Number of } \\
\text { firms }\end{array}$ \\
\hline Agriculture & 2 \\
Banking & 1 \\
Communication & 2 \\
Construction & 1 \\
Consulting & 20 \\
Education & 3 \\
Finance & 1 \\
Government & 5 \\
Health care & 3 \\
Manufacturing & 24 \\
Real estate & 1 \\
Retail & 4 \\
Software & 30 \\
Transportation & 3 \\
Other & 9 \\
\hline
\end{tabular}

\section{Operationalization of Constructs}

Existing multi-item scales were adapted whenever possible. Influence tactics measures were adapted from the influence behavior questionnaire developed by Yukl [71]. Project performance measures were adapted from Mahaney [33]. Since control loss had not been measured in an ISD project context, a systemic approach was followed to generate relevant items. First, case descriptions in published research and practitioner 
journals were thoroughly reviewed to identify instances of control loss. Cases in Kirsch [25, 26], Mähring [35], Perlow [46], and Walsham [64] and case descriptions of the famous IT failures listed in Nelson [40, 41] were examined. Second, professional documents such as the ITIL and PMBOK were used to identify appropriate terms and concepts. The ITIL gives a detailed description of a number of important IT practices with comprehensive checklists, tasks, and procedures for managing IT infrastructure, development, and operations. The PMBOK is published by the Project Management Institute to document and standardize project management information and practices. Third, the instrument was pretested by conducting interviews with IT project managers and IT professionals. This was done to establish face validity of the included items. The instrument was refined based on the feedback obtained during the pretest. Fourth, the refined instrument was pilot tested by 30 project managers, 30 team members, and 10 researchers in the IS community. All the changes were incorporated before final deployment. The constructs and items are shown in Appendix A.

\section{Measuring Congruence}

In this research, since the congruence is tested between related variables, influence tactics is captured from both the project manager and the team member. Congruence was defined based on the tenets of LMX, the FLM, and the managerial influence behavior literature $[17,71,73]$. In addition, we referenced how similar concepts were addressed within the IS research $[52,53]$. Based on our findings and as per the guidelines provided in Venkatraman [63], congruence was defined as "fit as matching." The argument is that in order to obtain successful outcomes, there must be shared understanding and agreement about the appropriateness of the chosen influence tactics. In other words, any misunderstanding or disagreements will lead to control loss. Fit exists when there are no differences between the project manager and the team member's understanding and consensus about the chosen tactics. Polynomial regression and response surface tests were used for data analysis following defined procedures [7, 8]. The absolute value of the difference between project manager and team member responses were considered for analysis. Congruence is not a single point but a line along which the component measures are equal. Incongruence is represented by perpendicular distance of the component scores from the line of congruence. A brief description of the procedure used is listed in Appendix B. Support for the hypotheses was determined using a set of constraints that are summarized in Table 5.

Two versions of the questionnaire were developed-one for project managers and another for team members. Both questionnaires had equivalent scales, which is one of the major requirements for computing congruence [8]. Communicational congruence was measured using a seven-point Likert scale ( 1 = "never used," 7 = "mostly used"); both project manager and team members were asked to reveal the extent to which each influence tactic was used. Perceptual congruence was captured using a seven-point Likert scale ( 1 = "not at all appropriate," 7 = "very appropriate"); the team members were asked to indicate the degree of appropriateness for each influence tactic. Control loss and project performance were measured on a seven-point Likert scale (1 = "strongly disagree," 7 = "strongly agree"), which was responded to by the project 
Table 5. Polynomial Regression Constraints and Implications

\begin{tabular}{|c|c|}
\hline Constraints & Implications \\
\hline $\begin{array}{l}\text { Significant coefficients on PM, } \\
\text { TM, WPM, and WTM but not W. }\end{array}$ & $\begin{array}{l}\text { The distribution is not skewed through the nonsig- } \\
\text { nificance of W. The significance of the PM and TM } \\
\text { coefficients illustrates that both the project manag- } \\
\text { ers' and the team members' perspectives have } \\
\text { direct effects on control loss. }\end{array}$ \\
\hline $\begin{array}{l}\text { Coefficients on PM and TM } \\
\text { are opposite in sign and } \\
\text { not significantly different in } \\
\text { absolute magnitude }\end{array}$ & $\begin{array}{l}\text { Verifies the general form of the model (i.e., control } \\
\text { loss is minimized rather than maximized along the } \\
\text { line of perfect congruence) and rules out situa- } \\
\text { tions in which constraints are resolved because all } \\
\text { of the coefficients are near zero. }\end{array}$ \\
\hline $\begin{array}{l}\text { Coefficients on WPM and WTM } \\
\text { are opposite in sign and } \\
\text { not significantly different in } \\
\text { absolute magnitude }\end{array}$ & $\begin{array}{l}\text { Determines whether the relative magnitudes of the } \\
\text { coefficients correspond to the model of inter- } \\
\text { est. } \mathrm{W} \text { is coded as } 0 \text { when } \mathrm{PM}-\mathrm{TM}>0,1 \text { when } \\
\mathrm{PM}-\mathrm{TM}<0 \text {. Because } \mathrm{PM}=\mathrm{TM} \text { was minimal } \\
\text { coding, } \mathrm{W} \text { either way does not affect the results. }\end{array}$ \\
\hline
\end{tabular}

Notes: $\mathrm{PM}=$ project manager; $\mathrm{TM}=$ team member; $\mathrm{WPM}=$ product of moderator variable and project manager; $\mathrm{WTM}=$ product of moderator variable and team member; $\mathrm{W}=$ moderator variable.

manager. Project performance was collected to determine the predictive validity of control loss. All the items and scales are listed in Appendix A.

The entire questionnaire was pretested and refined using a pilot sample of 30 matched pairs from industry and 10 academic experts. All the surveys were followed up with one- to two-hour personal interviews. During the pilot, it was found that the project managers failed to respond differently on the communication (is it used?) and the perception (is it appropriate?) scale for influence tactics. In the follow-up interviews, the project managers indicated they would not use something that is not appropriate. From a methodological standpoint, this presented a possibility of social desirability effect, which refers to individuals' tendency to present themselves in a favorable light, regardless of their true feelings about the issue or topic [49]. Several measures were taken to overcome this issue: (1) influence tactics were captured from different sources; (2) sources for socially desirable responses were captured - project manager and team member knowledge about the project, level of interpersonal trust between the project manager and team member, project manager and team members involvement in the project, and project complexity - and was tested for any possible effect on influence tactics; and (3) anonymity of responses was assured. These measures were consistent with the suggestions provided by Ganster et al. [14] and Podsakoff et al. [49]. More details are listed in Appendix C.

\section{Construct Analysis}

The control loss scale displayed good model fit for the second order model, all the factor loadings were above 0.7 (rho $=0.968$, CFI [comparative fit index $]=0.959$, 
RMSEA [root mean square error of approximation] $=0.048$, and $\chi^{2} / \mathrm{df}$ [degrees of freedom] = 1.38; see Appendix Table D1). Moreover, to ensure predictive validity for control loss, factor analyses (principal component extraction with varimax rotation) were done with both control loss items and project performance items. As expected, control loss and project performance loaded onto a separate factor (details of the analysis are summarized in Appendix D). More interestingly, control loss was negatively associated with project performance $(b=-0.241, p<0.05)$. The regression model was significant $(F=22.34, p<0.001)$ and explained significant variance $\left(R^{2}=0.364\right)$. The results are shown in Appendix $\mathrm{C}$.

For the influence tactics measures, prior research suggests either treating each tactic as an individual construct or grouping them it into meta-categories based on the research context [77]. In this study, the interest was on influence tactics congruence and not on any single tactic. Moreover, prior studies have noted that the managers usually use a combination of tactics rather than a single tactic [75]; thus, confirmatory factor analysis was done to test for influence tactics as a first- or second-order construct. The second-order model displayed better fit indices than the first-order model. All of the measures displayed good fit for the PM (project manager) use scale, the TM (team member) use scale, and the TM appropriateness scale-reliability (rho) of 0.973, 0.987, and 0.979, respectively; CFI of 0.921, 0.972, and 0.971, respectively; RMSEA of 0.052, 0.05, and 0.05, respectively (see Appendix Table D4). Since all the constructs displayed high reliability and no spurious correlations were detected, it was determined that responses based on social desirability was not an issue. Post hoc tests showed that the potential factors, which may trigger socially desirable responses, did not have any effect on the constructs. More details are listed in Appendix Table C1. The interconstruct correlations for the constructs are shown in Table 6.

\section{Analysis and Results}

H1 predicted that achieving communicational congruence regarding the chosen influence tactics will be negatively associated with control loss. Support for the hypothesis is determined by a set of constraints listed in Table 5 .

The results in Table 7 show that all the coefficients were significant except for the moderator variable $W$, thus validating communicational congruence. The coefficients $(0.40$ and $-0.78 ;-0.59$ and 0.65$)$ had opposite signs and were not significantly different in absolute magnitude. This suggests that achieving communicational congruence will reduce control loss [8]. In addition, this shows that control loss will be minimal along the line of congruence. Overall the model displayed good fit and explained significant variance $\left(R^{2}=0.66\right)$. The response surface tests were done to shed more insights on the hypothesized relationships.

The coefficient on $a_{1}$ was significant and $a_{2}$ was not; this implies a linear (additive) relationship along the line of congruence as it relates to control loss (see Figure 2). The coefficient on $a_{2}$ was negative, which indicates that control loss decreases as congruence increases. For the degree of discrepancy, the coefficient on $a_{4}$ was positive and significant implying that control loss would increase sharply as the discrepancy 
Table 6. Interconstruct Correlations

\begin{tabular}{lccccc}
\hline & 1 & 2 & 3 & 4 & 5 \\
\hline 1. PMTACTICS & 0.973 & & & & \\
2. TMTACTICSUSE & 0.042 & 0.987 & & & \\
3. TMTACTICSAPP & 0.066 & $0.925^{\star * \star}$ & 0.979 & & \\
4. CONTROLLOSS & 0.041 & $-0.654^{\star *}$ & $-0.670^{* *}$ & 0.968 & \\
5. PROJFPERFORMANCE & $0.403^{\star *}$ & 0.180 & 0.169 & $-0.300^{* *}$ & 0.931
\end{tabular}

Notes: PMTACTICS $=$ project manager response to tactics use scale; TMTACTICSUSE $=$ team member response to tactics use scale; TMTACTICSAPP = team member response to tactics appropriateness scale; CONTROLLOSS = project manager response to control loss scale; PROJFPERFORMANCE = project manager response to project performance scale. Cronbach's alphas are shown on the diagonal. *** Significant at the 0.01 level; ** significant at the 0.05 level.

Table 7. Influence Tactics Communicational Congruence and Control Loss

\begin{tabular}{ll} 
Independent variables & Beta \\
\hline Communicational congruence model & \\
PM & $0.40^{* \star *}$ \\
TM & $-0.78^{* \star *}$ \\
W & -0.051 \\
WPM & $-0.59^{* \star *}$ \\
WTM & $0.65^{* \star *}$ \\
$R^{2}$ & 0.66 \\
Adj. $R^{2}$ & 0.64 \\
$F_{c}$ & $29.37^{* * *}$ \\
Surface tests & \\
$a_{1}$ & $-0.24^{* \star *}$ \\
$a_{2}$ & -0.19 \\
$a_{3}$ & -0.01 \\
$a_{4}$ & $0.63^{* * *}$ \\
\hline$* p<0.05 ; * * p<0.01 ; * * * p<0.001$. & \\
\hline
\end{tabular}

increases. Finally, for the relationship between the direction of discrepancy and control loss, the coefficient on $a_{3}$ was not significant, which implies that control loss increases similarly as the congruence between PM and TM decreases in either direction. These results support our argument for describing communicational congruence as "fit as matching." In sum, these results provide support for $\mathrm{H} 1$.

$\mathrm{H} 2$ predicts that achieving perceptual congruence regarding the appropriateness of influence tactics will be negatively associated with control loss. The results in Table 8 show overall support for this hypothesis.

The coefficient on the moderator variable $W$ was not significant, which justifies the perceptual congruence model. The coefficients ( -0.44 and 0.67$)$ had opposite signs and were not significantly different in absolute magnitude, which suggests that con- 


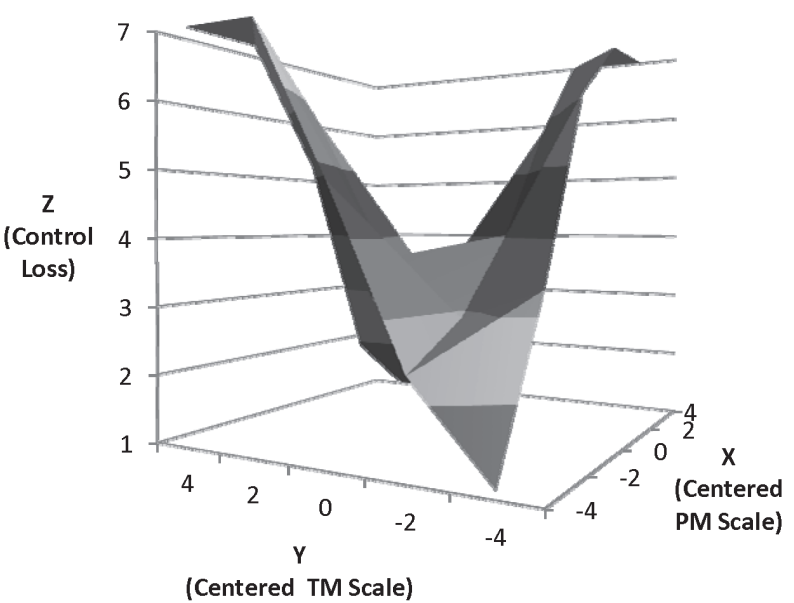

Figure 2. Influence Tactics Communicational Congruence and Control Loss

Table 8. Influence Tactics Perceptual Congruence and Control Loss

\begin{tabular}{ll} 
Independent variables & Beta \\
\hline Perceptual congruence model & \\
PM & $0.21^{* \star}$ \\
TM & $-0.73^{\star \star *}$ \\
W & -0.15 \\
WPM & $-0.44^{\star \star *}$ \\
WTM & $0.67^{* * *}$ \\
$R^{2}$ & 0.65 \\
Adj. $R^{2}$ & 0.62 \\
$F_{c}$ & $27.34^{* \star *}$ \\
Surface tests & \\
$a_{1}$ & $-0.25^{*}$ \\
$a_{2}$ & $-0.22^{* *}$ \\
$a_{3}$ & 0.01 \\
$a_{4}$ & $0.74^{\star * *}$ \\
\hline$* p<0.05 ; * * p<0.01 ; * * * p<0.001$. &
\end{tabular}

trol loss will be minimal along the line of congruence. Overall, the model explained significant variance $\left(R^{2}=0.65\right)$. Response surface tests were done to determine how control loss varies as perceptual congruence changes.

The response surface tests for $a_{1}$ and $a_{2}$ were negative and significant, which indicates a possibility of nonlinear slope of the line of perfect agreement (see Figure 3). From a control loss standpoint, this indicates that control loss could decrease or increase more sharply as both the PM and TM scores become higher or lower from some point. For the degree of discrepancy between influence tactic perceptual congruence and control loss, $a_{4}$ was significant and positive, which implies that control loss increases more sharply as the degree of discrepancy increases. Finally, the direction of discrepancy 


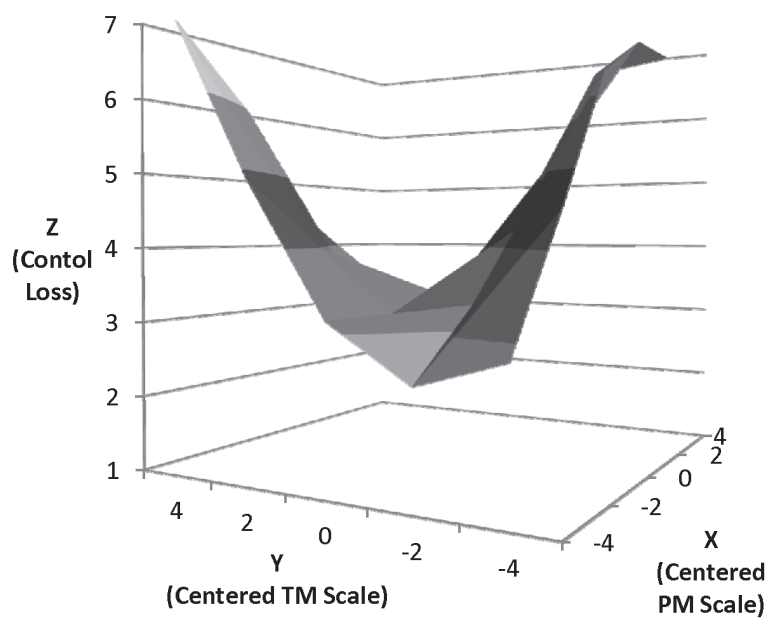

Figure 3. Influence Tactics Perceptual Congruence and Control Loss

does not matter since $a_{3}$ was not significant. In other words, control loss is similarly increased by dips in both PM and TM disagreement regarding the appropriateness of influence tactics. This also provided support for defining perceptual congruence as "fit as matching." The results of this analysis provide support for $\mathrm{H} 2$.

\section{Discussion and Implications}

THE UNCERTAINTY IN ISD PROJECTS, coupled with their typically high failure rate, suggests that more research is needed on effective management of these projects. One of the main objectives of this study was to explore the dynamics involved in managing ISD projects. This study developed three underlying ideas that contribute to this overarching perspective. First, as ISD projects become increasingly complex and require highly skilled team members; project managers need to maintain a balance of management and leadership. The project manager has to focus on developing a highquality exchange relationship. Second, the findings indicate that developing congruent values between the project manager and team members with respect to management practices can help alleviate problems occurring while the project is being developed. To this end, we presented a congruence framework and assessed two types of congruencies: communicational congruence and perceptual congruence. The rationale for the congruence framework was drawn from LMX theory and the FLM. Third, we developed an intermediate outcome variable, control loss, to capture the intermediary slippages occurring during project development.

\section{Implications for Research}

ISD project failures can be expensive and have dire consequences on organizational performance [22]; moreover, ISD projects involve knowledge-intensive tasks that must 
be performed by highly skilled team members [61]. It is important to reach beyond management of contracts and move toward management of relationships. This study depicts the importance of both management and leadership in ISD projects by showing its effect on control loss. In particular, the two types of congruence-communicational congruence and perceptual congruence-displayed significant effects on control loss. For communicational congruence, the results indicate that as congruence increases control loss decreases. For perceptual congruence, the surface tests reveal the possibility of a sharp increase in control loss with an increase in discrepancy.

The congruence framework presented in this study offers a nuanced approach for examining fit between various stakeholders involved in ISD projects. Within the IT project management literature, studies have attempted to asses measures similar to congruence using broader terms, such as alignment or social alignment, to capture the degree of consensus between the involved parties with respect to social aspects of projects (e.g., [53]). However, most of these studies have found mixed or weak support. One of the major problems was associated with the approach used to evaluate alignment. This study used polynomial regression and response surface tests to examine an important aspect of alignment. The results for both the models displayed good fit and provided a clear understanding of how each component affected the dependent variable. Using such robust approaches can provide a detailed understanding of relationships between combinations of two predictor variables and an outcome variable by graphing the results onto a three-dimensional space.

Previous studies have constantly attempted to improve or refine project performance measures (e.g., [3, 54]). This study contributes to the project performance nomological net by introducing the intermediate outcome variable-control loss. Control loss was prominent in all the projects considered in this study ( mean $=3.57$, maximum $=6.56$, $\mathrm{SD}=1.06$ ); furthermore, the measures developed support constructs and findings developed from ISD project cases. These findings suggest that testing the effect of project management techniques on intermediary outcome variables, rather than final outcomes, can help generate rich implications for improving project performance. In fact, simply capturing intermediary problems can itself be used as a strategy to improve project performance. Similarly, using control loss in conjunction with other intermediary measures such as performance residual risk, schedule, and cost variance may not only help in gaining better insight but it could also help extend the project performance nomological net.

The overarching implication of the study is that both the project manager and the team members play a vital role in fostering ISD project success; thus, it is important to consider both these entities while exploring ISD project management. From a project performance standpoint, introducing ex ante measures is important to develop rich implications for improving project success.

\section{Implications for Practice}

These findings offer a number of implications for project managers. Team effectiveness matters to individuals, to organizations, and to projects. Recent IT trends, such as global 
systems, virtual teams, and offshore sourcing have only increased the importance of effective teams [21]. Several case reports indicate that developer's misunderstandings, team conflicts, and poor team relationships are major causes for project failure [38, $40,41]$. Thus, the overarching question is how to facilitate the project managerteam member relationship in order to promote project success. One possible way to achieve this is to foster high-quality exchange relationships. As a project manager, it is important to understand the involved members' values and attitudes, communicate clearly, and consider their opinions. This perspective is supported by the congruence framework presented in this study. For instance, project managers can use perceptual congruence as an instrument to obtain feedback about their project management practices. Doing so will help foster a climate in which disagreements can be discussed constructively and in turn boost team motivation. Similarly, communicational congruence can be used to determine effectiveness of communication structures to ensure that all of the team members are aptly informed regarding decisions or changes. In sum, ensuring that goals and objectives are clearly spelled out and the activities and tasks necessary to meet these goals are uniformly understood will give the team a shared sense of purpose.

Finally, the intermediate outcome variable control loss can be used to detect the problems occurring while the project is still being developed. This will give the project manager an opportunity to make necessary adjustments to ensure that the project is progressing in the right direction. From a broader perspective, the project manager and senior management can use control loss as an evaluation mechanism to determine project progress and make well-informed use of available resources. This, in turn, can be used to determine if the project should be continued, thus reducing potential sunk costs. Table 9 provides a summary of implications for both practice and research.

\section{Limitations}

As WITH ALL RESEARCH, THIS STUDY IS SUBJECT TO LIMITATIONS that must be considered when evaluating its implications. This study focused on the project manager-team dyadic relationship; however, an ISD project involves various stakeholders, such as business managers, users, and external vendors. In an ideal situation, congruence with respect to all stakeholders and its impact on control loss should be examined. A possible way to do this is to employ qualitative approaches and conduct an in-depth case analysis on an appropriate ISD project. Similarly, it would be interesting to examine the direct and indirect effects of influence tactics on project success and control loss.

The responses from the project managers and the team members were collected at the same time. As a result, there were some downfalls; for instance, the correlation between the project manager and team member responses was on the lower side. Ideally, the data should have been collected longitudinally, which may give the team members more opportunity to realize the tactics; however, this was not possible because of the difficulties already imposed by dyadic data. For example, prior research involving dyadic data has reported a sample size in the range of 42-60 (e.g., [20, 28]). 
Table 9. Summary of Findings and Implications to Research and Practice

\begin{tabular}{|c|c|c|}
\hline Findings & $\begin{array}{l}\text { Implications for } \\
\text { research }\end{array}$ & $\begin{array}{l}\text { Implications for } \\
\text { practice }\end{array}$ \\
\hline $\begin{array}{l}\text { Congruence framework } \\
\text { strongly supported }\end{array}$ & $\begin{array}{l}\text { Consider both manager and team } \\
\text { perspective while assessing } \\
\text { monitoring mechanisms. } \\
\text { Use similar frameworks to capture } \\
\text { fit, agreement, and social } \\
\text { alignment. }\end{array}$ & $\begin{array}{l}\text { Harmonization helps } \\
\text { improve team } \\
\text { effectiveness. }\end{array}$ \\
\hline $\begin{array}{l}\text { Communicational } \\
\text { congruence was } \\
\text { effective in alleviating } \\
\text { control loss }\end{array}$ & $\begin{array}{l}\text { Exploring communicational } \\
\text { congruence can help better } \\
\text { understand how to improve } \\
\text { effectiveness of monitoring } \\
\text { techniques, i.e., reducing } \\
\text { redundancy and enhancing } \\
\text { dexterity in completing tasks. }\end{array}$ & $\begin{array}{l}\text { Establishing formal } \\
\text { communication } \\
\text { structures can } \\
\text { improve coordination } \\
\text { and avoid slippages } \\
\text { in achieving original } \\
\text { intentions. }\end{array}$ \\
\hline $\begin{array}{l}\text { Perceptual congruence } \\
\text { was effective in } \\
\text { alleviating control } \\
\text { loss }\end{array}$ & $\begin{array}{l}\text { Exploring perceptual congruence } \\
\text { can shed richer insights into } \\
\text { motivational issues surfacing in } \\
\text { ISD projects. } \\
\text { It can help understand why certain } \\
\text { monitoring techniques fail in an } \\
\text { ISD project environment. }\end{array}$ & $\begin{array}{l}\text { Encouraging team } \\
\text { members to discuss } \\
\text { disagreements } \\
\text { constructively can } \\
\text { motivate them to } \\
\text { perform better and } \\
\text { keep things under } \\
\text { control. }\end{array}$ \\
\hline $\begin{array}{l}\text { Control loss was } \\
\text { prominent and had } \\
\text { adverse effect on } \\
\text { project performance }\end{array}$ & $\begin{array}{l}\text { Focus on developing measures that } \\
\text { will help capture the problems } \\
\text { occurring while the project } \\
\text { is being developed. This can } \\
\text { help resolve issues such as } \\
\text { gold plating and fuzzy product } \\
\text { development. }\end{array}$ & $\begin{array}{l}\text { It is important to } \\
\text { address the problems } \\
\text { as they occur rather } \\
\text { than wait until the } \\
\text { completion of the } \\
\text { project. }\end{array}$ \\
\hline
\end{tabular}

This study examined the consequences of any misunderstanding and disagreements between the project manager and the team member regarding the chosen influence tactic; however, it is possible that external factors such as degree of standardization [43] or the existing client-IS manager relationship [28] can affect the choice of an influence tactic. Accordingly, future research might examine why a project manager uses a certain tactic and also why there might be a disagreement or misunderstanding between the project manager and team members regarding the influence tactic.

For the project manager section of the survey, there was some possibility of social desirability effect; however, several measures were put in place to ensure that this limitation did not affect the validity of the results. For instance, the project managers were asked about their knowledge about the project, their involvement in the project from the initiation phase, and their autonomy in forming teams (among others). In addition, all the constructs had high scale reliability with no indication of spurious correlations among them. 
Finally, the focus of this study was on internally developed ISD projects. Recent studies reveal that outsourcing and offshoring are becoming prominent trends in the IT industry (e.g., [21]). This fact may raise questions about the generalizability of this study's findings to those contexts. Nevertheless, the arguments developed can be easily extended to these contexts.

\section{Directions for Future Research}

THESE FINDINGS PROVIDE FOUR PROMISING VENUES FOR FUTURE RESEARCH. First, the congruence framework presented here can be extended to other monitoring techniques, such as control modes and governance, to see how congruence with respect to these factors affects project outcomes. Also, the framework may be extended to study harmonization at various management levels. For instance, exploring the impact of harmonization between the IT project manager and business manager on project success would provide valuable insights. Second, the theoretical lenses such as LMX and FLM used in this research may be expanded to examine the dynamics of other areas in ISD project management. Using various theoretical lenses may help develop a holistic understanding of ISD project management and leadership. Third, recent trends indicate the increasing growth of virtual teams and distributed teams in organizational workplaces [23]. Thus, examining the role of influence tactics in these settings could be a worthwhile effort. Fourth, previous studies (e.g., [45]) have noted that control loss may be cumulative in nature. Longitudinal approaches could be utilized to examine changes in control loss over time; for instance, exploring whether control loss increases, if not addressed, will help us better understand the nature of control loss in ISD projects. In terms of project escalation, it would be interesting to know if a project deescalates at a certain level of control loss.

\section{Conclusion}

OVERALL, THIS STUDY PRESENTED A SIMPLE BUT UNIQUE APPROACH to understanding ISD project management, focusing on the congruity between the project manager and the team members. Understanding the dynamics of a dyadic relationship is important in today's ISD project environments, which are dynamic and increasingly demand adaptive/flexible new leadership styles. Recent trends indicate that IS knowledge workers prefer to be more participative rather than being delegated [21]. Accordingly, it is vital for project managers to structure relationships, bearing in mind what the team members bring to the project, and continually evaluate their approach to manage the team. By having a common understanding of influences, the project manager can gain greater traction with team members to change course or engage in other cooperative behaviors. From a performance standpoint, given the huge sunk costs involved in an ISD project, it is important for the stakeholders to be proactive and continually monitor project progress rather than categorically classifying the project as failed post hoc. To this end, examining and understanding "control loss" offers a more progressive 
way of thinking about project diagnostics and presents opportunities for corrective actions. In other words, addressing problems as they occur may help foster project success as well as help to develop better project management practices for managing future projects.

\section{REFERENCES}

1. Abdel-Hamid, T.K. Understanding the "90\% syndrome" in software project management: A simulation-based case study. Journal of Systems and Software, 8, 4 (1988), 319-330.

2. Abdel-Hamid, T.K., and Madnick, E.S. The elusive silver lining: How we fail to learn from software development failures. Sloan Management Review, 32, 1 (1990), 39-48.

3. Aldawani, A.M. An integrated performance model of information systems projects. Journal of Management Information Systems, 19, 1 (Summer 2002), 185-210.

4. Cannon-Bowers, J.A.; Salas, E.; and Converse, S.A. Cognitive psychology and team training: Shared mental models in complex systems. Human Factors Society Bulletin, 33, 1 (1990), 1-4.

5. Dansereau, F.; Graen, G.; and Haga, W.J. A vertical dyadic linkage approach to leadership within formal organizations: A longitudinal investigation of the role making process. Organizational Behavior and Human Performance, 13, 1 (1975), 46-78.

6. DeLone, H.W., and McLean, E.R. The DeLone and McLean model of information systems success: A ten-year update. Journal of Management Information Systems, 19, 4 (Spring 2003), 9-30.

7. Edwards, J.R. The study of congruence in organizational behavior research: Critique and a proposed alternative. Organizational Behavior and Human Decision Processes, 58, 25 (1994), 51-100.

8. Edwards, J.R. Alternatives to difference scores as dependent variables in the study of congruence in organizational research. Organizational Behavior and Human Decision Processes, 64, 3 (1995), 307-324.

9. Evans, P. Multiple hierarchies and organizational control. Administrative Science Quarterly, 20, 2 (1975), 250-259.

10. Evans, P. Reducing control loss in organizations: The implications of dual hierarchies, mentoring and strengthening vertical dyadic linkages. Management Science, 30, 2 (1984), $156-168$.

11. Falbe, C.M., and Yukl, G. Consequences for managers of using single influence tactics and combinations of tactics. Academy of Management Journal, 35, 3 (1992), 638-652.

12. Faraj, S., and Sambamurthy, V. Leadership of information systems development projects. IEEE Transactions on Engineering Management, 53, 2 (2006), 228-249.

13. Flyvbjerg, B., and Budzier, A. Why your IT project may be riskier than you think. Harvard Business Review, 89, 9 (September 2011), 601-603.

14. Ganster, D.C.; Hennessey, H.W.; and Luthans, F. Social desirability response effects: Three alternative models. Academy of Management Journal, 26, 2 (1983), 321-331.

15. Gibbs, W. Software's chronic crisis. Scientific American (September 1994), 86-95.

16. Graen, G., and Cashman, J. A role-making model of leadership in formal organizations: A developmental approach. In J.G. Hunt and L.L. Larson (eds.), Leadership Frontiers. Kent, OH: Kent State University Press, 1975, pp. 143-165.

17. Graen, B.G., and Uhl-Bein, M. Relationship-based approach to leadership: Development of leader-member exchange (LMX) theory of leadership over 25 years: Applying a multi-level multi-domain perspective. Leadership Quarterly, 6, 2 (1995), 219-247.

18. Graen, G.; Novak., M.; and Sommerkamp, P. The effects of leader-member exchange and job design on productivity and satisfaction: Testing a dual attachment model. Organizational Behavior and Human Performance, 30, 1 (1982), 109-131.

19. Guinan, P.J.; Cooprider, J.G.; and Faraj, S. Enabling software development team performance during requirements definition: A behavioral versus technical approach. Information System Research, 9, 2 (1998), 101-125. 
20. Henderson, J.C., and Lee, S. Managing I/S design teams-A control theories perspective. Management Science, 38, 6 (1992), 757-777.

21. Hirschheim, R.; Heizl, A.; and Dibbern, J. Information Systems Outsourcing: Enduring Themes, Global Challenges, and Process Opportunities. New York: Springer, 2006.

22. Hoque, F.; Sambamurthy, V.; Zmud, R.W.; Trainer, T.; and Wilson, C. Winning the 3-Legged Race: When Business and Technology Run Together. Upper Saddle River, NJ: Prentice Hall, 2005.

23. Jury, A.W. Leadership effectiveness within virtual teams: investigating mediating and moderating mechanisms. Ph.D. dissertation, School of Psychology, University of Queensland, Australia, 2008.

24. Kerr, N.L., and Bruun, S. The dispensability of member effort and group motivation losses: Free-rider effects. Journal of Personality and Social Psychology, 44, 1 (1983), 78-94.

25. Kirsch, L.J. Portfolios of control modes and IS project management. Information Systems Research, 8, 3 (1997), 215-239.

26. Kirsch, L.J. Deploying common systems globally: The dynamics of control. Information Systems Research, 15, 4 (2004), 374-395.

27. Kirsch, L.J.; Ko, D.-G.; and Haney, M.H. Investigating the antecedents of team-based clan control: Adding social capital as a predictor. Organization Science, 21, 2 (2010), 469-489.

28. Kirsch, L.J.; Sambamurthy, V.; Ko, D.-G.; and Purvis, R.L. Controlling information systems development projects: The view from the client. Management Science, 48, 4 (2002), 484-498.

29. Lam, W.; Huang, X.; and Snape, E. Feedback seeking behavior and leader-member exchange: Do supervisor-attributed motives matter? Academy of Management Journal, 50, 2 (2007), 348-363.

30. Leifer, R., and Mills, P.K. An information processing approach for deciding upon control strategies and reducing control loss in emerging organizations. Journal of Management, 22, 1 (1996), 113-137.

31. Lord, R.G. An information processing approach to social perceptions, leadership and behavioral measurement in organizations. In L.L. Cummings and B.M. Staw (eds.), Research in Organizational Behavior, vol. 7. Greenwich, CT: JAI Press, 1985, pp. 87-128.

32. Lord, R.G., and Maher, K.J. Leadership and Information Processing: Linking Perceptions and Performance. Boston: Routledge, 1991.

33. Mahaney, R.C. Information systems development project success and failure: An agency theory interpretation. Ph.D. dissertation, Department of Management, University of Kentucky, Lexington, 2000.

34. Mahaney, R.C., and Lederer, A.L. Information systems project management: An agency theory interpretation. Journal of Systems and Software, 68, 1 (2003), 1-9.

35. Mähring, M. IT project governance: A process-oriented study of organizational control and executive involvement. Working Paper in Business Administration, Stockholm School of Economics-Economic Research Institute, Stockholm, 2002.

36. Marks, M.; Zaccaro, S.J.; and Mathieu, J. Performance implications of leader briefings and team interaction training for team adaptation to novel environments. Journal of Applied Psychology, 85, 6 (2000), 971-986.

37. Maslyn, J.M., and Uhl-Bien, M. Leader-member exchange and its dimensions: Effects of self-effort and other's effort on relationship quality. Journal of Applied Psychology, 86, 4 (2001), 697-708.

38. McCafferty, D. IT management slideshow: Five enterprise project management mistakes to avoid. CIO Insight, March 15, 2012 (available at www.cioinsight.com/c/a/IT-Management/ Five-Enterprise-Project-Management-Mistakes-to-Avoid-130217/).

39. McConnell, S. Software Estimation: Demystifying the Black Art. Redmond, WA: Microsoft Press, 2006.

40. Nelson, R.R. Project retrospectives: Evaluating project success failure and everything in between. MIS Quarterly Executive, 4, 3 (2005), 361-372.

41. Nelson, R.R. IT project management: Infamous failures, classic mistakes, and best practices. MIS Quarterly Executive, 6, 2 (2007), 67-78.

42. Nidumolu, S.R. The effect of coordination and uncertainty on software project performance: Residual performance risk as an intervening variable. Information System Research, 6, 3 (1995), 191-219. 
43. Nidumolu, S.R., and Subramani, M.R. The matrix of control: Combining process and structure approaches to managing software development. Journal of Management Information Systems, 20, 3 (Winter 2003-4), 159-196.

44. Ouchi, W.G. The relationship between organizational structure and organizational control. Administrative Sciences Quarterly, 22, 1 (1977), 95-113.

45. Ouchi, W.G. The transmission of control through organizational hierarchy. Academy of Management Journal, 21, 2 (1978), 173-192.

46. Perlow, L.A. Boundary control: The social ordering of work and family time in a hightech corporation. Administrative Science Quarterly, 43, 2 (1998), 328-357.

47. Pescosolido, A.T. Informal leaders and the development of group efficacy. Small Group Research, 32, 1 (2001), 74-93.

48. Pfeffer, J., and Salancik, J. The External Control of Organizations: A Resource Dependence Perspective. New York: Harper \& Row, 1978.

49. Podsakoff, P.M.; MacKenzie, S.B.; Lee, J.-Y.; and Podsakoff, N.P. Common method bias in behavioral research: A critical review of the literature and recommended remedies. Journal of Applied Psychology, 88, 5 (2003), 879-903.

50. Project Management Institute. A Guide to the Project Management Body of Knowledge (PMBOK ${ }^{\circledR}$ Guide), 10th Anniversary Limited Edition. Pittsburgh: Project Management Institute, 2006.

51. Pulakos, E.D., and Wexley, K.N. The relationship among perceptual similarity, sex, and performance ratings in manager-subordinate dyads. Academy of Management Journal, 26, 1 (1983), 129-139.

52. Reich, B.H., and Benbasat, I. Measuring the linkage between business and information technology Objectives. MIS Quarterly, 20, 1 (1996), 55-81.

53. Reich, B.H., and Benbasat, I. Factors that influence the social dimension of alignment between business and information technology objectives. MIS Quarterly, 24, 1 (2000), 81-111.

54. Saarinen, T. An expanded instrument for evaluating information system success. Information \& Management, 31, 2 (1996), 103-118.

55. Scandura, T.A.; Graen, G.B.; and Novak, M.A. When managers decide not to decide autocratically: An investigation of leader-member exchange and decision influence. Journal of Applied Psychology, 71, 4 (1986), 579-584.

56. Schriesheim, C.A.; Neider, L.L.; and Scandura, T.A. Delegation and leader-member exchange: Main effects, moderators, and measurement issues. Academy of Management Journal, 41, 3 (1998), 298-318.

57. Schriesheim, J.F. The social context of leader-subordinate relations: An investigation of the effects of group cohesiveness. Journal of Applied Psychology, 65, 2 (1980), 183-194.

58. Settoon, R.P.; Bennett, N.; and Liden, R.C. Social exchange in organizations: Perceived organizational support, leader-member exchange, and employee reciprocity. Journal of Applied Psychology, 81, 3 (1996), 219-227.

59. Shanock, L.R.; Baran, B.E.; Gentry, W.A.; Pattison, S.C.; and Heggestad, E.D. Polynomial regression with response surface analysis: A powerful approach for examining moderation and overcoming limitations of difference scores. Journal of Business and Psychology, 25, 4 (2010), 543-554.

60. Sparrowe, R.T.; Soetjipto, B.W.; and Kraimer, M.L. Do leaders' influence tactics relate to members' helping behavior? It depends on the quality of the relationship. Academy of Management Journal, 49, 6 (2006), 1194-1208.

61. Tiwana, A. Governance-knowledge fit in systems development projects. Information Systems Research, 20, 2 (2009), 180-197.

62. Tiwana, A., and Keil., M. Control in internal and outsourced software projects. Journal of Management Information Systems, 26, 3 (Winter 2009-10), 9-44.

63. Venkatraman, N. The concept of fit in strategy research: Toward verbal and statistical correspondence. Academy of Management Review, 14, 3 (1989), 423-444.

64. Walsham, G. Cross-cultural software production and use: A structurational analysis. MIS Quarterly, 26, 2 (2002), 359-380.

65. Weldon, E., and Weingart, L.R. Group goals and group performance. British Journal of Social Psychology, 32, 4 (1993), 307-334. 
66. Wexley, K.N., and Pulakos, E.D. The effects of perceptual congruence and sex on subordinates performance appraisals of their managers. Academy of Management Journal, 26, 4 (1983), 666-676.

67. Williamson, O. Hierarchical control and optimum firm size. Journal of Political Economy, 75, 2 (1967), 123-138.

68. Yourdon, E. Death March. Upper Saddle River, NJ: Prentice Hall, 2003.

69. Yukl, G.A. Managerial leadership: A review of theory and research. Yearly Review of Management, 15 (1989), 251-289.

70. Yukl, G. Flexible Leadership: Creating Value by Balancing Multiple Challenges and Choices. San Francisco: Jossey-Bass, 2004.

71. Yukl, G. How leaders influence organizational effectiveness. Leadership Quarterly, 19, 6 (2008), 708-722.

72. Yukl, G., and Falbe, C.M. Influence tactics in upward, downward, and lateral influence attempts. Journal of Applied Psychology, 75, 2 (1990), 132-140.

73. Yukl, G., and Lepsinger, R. Why integrating the leading and managing roles is essential for organizational effectiveness. Organizational Dynamics, 34, 4 (2005), 361-375.

74. Yukl, G.A., and Tracy, J.B. Consequences of influence tactics used with subordinates, peers and the boss. Journal of Applied Psychology, 77, 4 (1992), 525-535.

75. Yukl, G.; Guinan, P.J.; and Sottolano, D. Influence tactics used for different objectives with subordinates, peers, and superiors. Group \& Organization Management, 20, 3 (1995), 272-296.

76. Yukl, G.; O’Donnell, M.; and Taber, T. Leader behaviors and leader-member exchange. Journal of Managerial Psychology, 24, 4 (2009), 298-299.

77. Yukl, G.; Seifert, C.; and Chavez, C. Validation of the extended influence behavior questionnaire. Leadership Quarterly, 19, 5 (2008), 609-621.

78. Zaccaro, S.J.; Rittman, A.L.; and Marks, M.L. Team leadership. Leadership Quarterly, 12, 4 (2001), 451-483.

79. Zacarro, S.J.; Gilbert, J.A.; Thor, K.K.; and Mumford, M.D. Leadership and social intelligence: Linking social perspectiveness and behavioral flexibility to leader effectiveness. Leadership Quarterly, 2, 4 (1991), 317-342. 


\section{Appendix A: Construct Measures}

Table A1. Control Loss Items

CLP1 Team members are not responsive to the project manager

CLP2 Team members spend time working on the wrong tasks

CLP3 Team members spend time on tasks other than their assigned duties

CLP4 Team members often do not follow development processes (e.g., design and code reviews)

CLP5 It is difficult to get team members to complete assigned tasks.

CLP6 Overall, there is not enough control over team members

LPR1 The development process does not adheres to auditability and control standards

LPR2 The development process adheres to the recommended methodology*

LPR3 The "change control process" is under control*

LPR4 The project schedule is under control*

LPR5 Project costs are under control*

LPR6 Overall, there is control over technical processes*

LPR7 Overall, there is control over management processes*

LRE1 The assigned tasks are performed using more than required technical resources

LRE2 Project suffered from resource battles, negatively impacting project schedule

LRE3 Project suffered from resource battles, negatively impacting project costs

LRE4 There is irrational use of allocated resources

LRE5 Resources are deployed when they are needed*

LRE6 Resources are available when they are needed*

LRE7 There is no maximum utilization of allocated resources

LRE8 Overall, there is not enough control over allocated resources

CL Overall, this project is out of control

Notes: 1 = "strongly disagree," 7 = "strongly agree." CLP = loss of control over people,

$\mathrm{LPR}=$ loss of control over processes, $\mathrm{LRE}=$ loss of control over resources, $\mathrm{CL}=$ overall control loss item. * Reverse-scaled item. 
Table A2. Survey Items-Influence Tactics

For this project I . . .

Rational persuasion

... use facts and logic to make a persuasive case for a request or proposal.

... explain clearly why a request or proposed activity is necessary to attain a task objective.

... explain why a proposed task or change would be practical and cost effective.

... provide information or evidence to show that a proposed activity or task is likely to be successful.

Ingratiation

... say that a proposed activity or task is an opportunity to do something really exciting and worthwhile.

... describe a clear, inspiring vision of what a proposed task or activity could accomplish.

... talk about values and ideals when proposing a new activity or task.

... make an inspiring speech or presentation to arouse enthusiasm for a proposed activity or task.

Legitimating

... say that my request or proposal is consistent with official rules and policies.

... say that my request or proposal is consistent with a prior agreement or contract.

... verify that a request is legitimate by referring to a document such as a work order, policy manual, charter, bylaws, or contract.

... say that a request or proposal is consistent with prior precedent and established practice.

Pressure

... demand that the team members carry out a request.

... use threats or warnings when trying to get the team members to do something.

... repeatedly check to see if the team members have carried out a request.

... try to pressure the team members to carry out a request.

Collaboration

... offer to provide any assistance the team members need to carry out a request.

... offer to provide resources the team members would need to do a task for you.

... offer to show the team members how to do a task that you want them to carry out.

... offer to help with a task you want the team members to carry out.

Consultation

... ask the team members to suggest things they could do to help you achieve a task objective or resolve a problem.

... consult with the team members to get their ideas about a proposed activity or task that you want them to support or implement.

... encourage the team members to express any concerns about a proposed activity or task that you want them to support or implement.

... invite the team members to suggest ways to improve a preliminary plan or proposal that you want them to support or help implement.

Coalition

... mention the names of others who endorse a proposal when asking the team members to support it.

... get others to explain why they support a proposed activity or change that you want team members to support or help implement.

... bring someone along for support when meeting with the team members to make a request or proposal.

... ask someone the team members respect to help influence them to carry out a request or support a proposal

Notes: The items were adapted from Yukl et al. [76]. Two separate scales were created to assess communicational congruence ( 1 = "never used," 7 = "mostly used") and perceptual congruence (1 = "not at all appropriate," 7 = "very appropriate"). 
Table A3. Survey Items for Project Performance

PP1 The project will be completed within its original schedule

PP2 The project will be completed within its original budget

PP3 Deliverables are meeting all of the expectations originally specified

PP4 The scope of this project is meeting the original specifications

PP5 This project is actually performing as well as planned

PP6 Overall, this project will be completed successfully

Note: Items were adapted from Mahaney [33]; 1 = "strongly disagree," 7 = "strongly agree."

\section{Appendix B: Polynomial Regression and Response Surface Tests}

The following procedure is BASEd on Edwards [7]. $X$ and $Y$ correspond to project manager and team member responses.

$$
\text { Model 2: } Z=b_{0}+b_{1} X+b_{2} Y+b_{3} W+b_{4} W X+b_{5} W Y+e .
$$

\section{Testing Process}

Step 1

Compute the difference between $X$ and $Y$ for each scale.

\section{Step 2}

Assign the difference to $W$, a separate predictor to obtain unbiased estimates of the coefficients on the product terms $W X$ and $W Y$.

\section{Step 3}

The value of $W$ is set to 0 or 1 , when $X=Y$. However, screening the data revealed that cases with $X=Y$ were minimal compared to the total sample size. This was true for both communicational and perceptual congruencies. This also indicates that number of tactics did not inflate the fit.

\section{Step 4}

Support for the two congruence models were determined by testing the following constraints (1) $b_{1}=-b_{2}$, (2) $b_{4}=-b_{5}$, (3) $b_{3}=0$, and (4) $b_{4}=-2 b_{1}^{2}$ individually.

\section{Step 5}

Response surface graphs were constructed based on the procedures defined by Shanock et al. [59]. 
Step 6

Unstandardized regression coefficients, associated standard errors, and covariance were determined for the coefficients in the polynomial regression model $Z=b_{0}+b_{1} X+$ $b_{2} Y+b_{3} X^{2}+b_{4} X Y+b_{5} Y^{2}$.

\section{Step 7}

Surface values $a_{1}=\left(b_{1}+\mathrm{b}_{2}\right), a_{2}=\left(b_{3}+b_{4}+b_{5}\right), a_{3}=\left(b_{1}-b_{2}\right)$, and $a_{4}=\left(b_{3}-b_{4}+b_{5}\right)$ were computed, and significance tests for surface values were conducted using the formulas listed in Shanock et al. [59]:

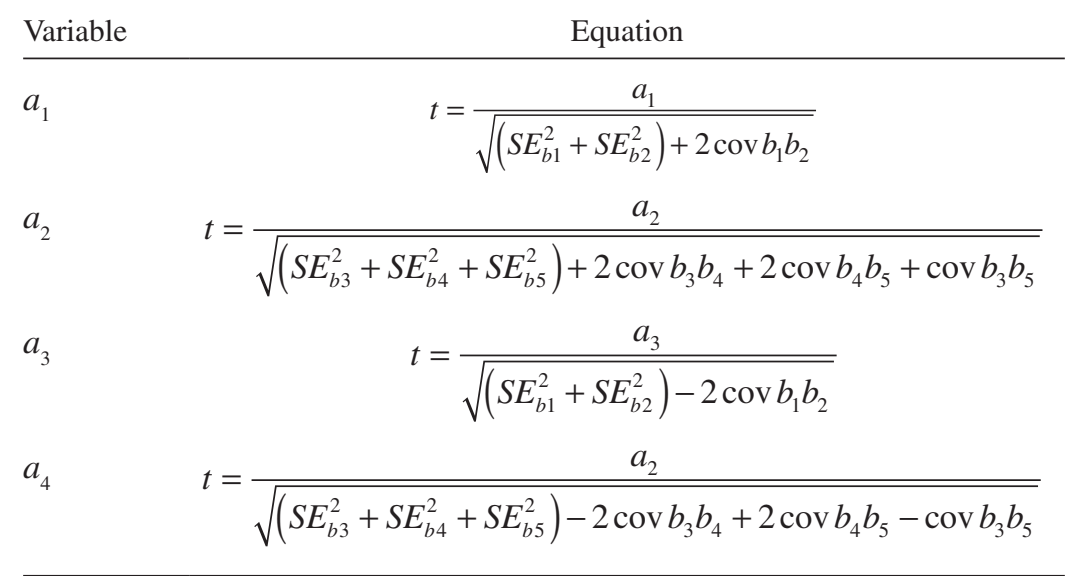




\section{Appendix C: Control Variables}

THE FACTORS IN TABLE C1 WERE CAPTURED to detect any socially desirable responses. The rationale was to explore the project manager's faked responses to the items. An analysis of variance was done to determine any possible effect on all the constructs. The results in Table $\mathrm{C} 1$ show that none of the factors influenced the responses, therefore eliminating the possibility of socially desirable effect.

Table C1. Project Phase and Influence Tactics

\begin{tabular}{|c|c|c|c|c|}
\hline Factor & $\begin{array}{l}\text { Sum of } \\
\text { squares }\end{array}$ & $\begin{array}{l}\text { Degrees of } \\
\text { freedom }\end{array}$ & $F$ & Significance \\
\hline \multicolumn{5}{|l|}{ Project phase } \\
\hline PM tactics & 9.87 & 4 & 2.31 & NS \\
\hline TM tactics use & 9.91 & 4 & 1.81 & NS \\
\hline TM tactics appropriate & 2.48 & 4 & 0.61 & NS \\
\hline Control loss & 9.98 & 4 & 1.88 & NS \\
\hline \multicolumn{5}{|l|}{ Project percent complete } \\
\hline PM tactics & 22.23 & 22 & 0.992 & NS \\
\hline TM tactics use & 42.79 & 22 & 1.52 & NS \\
\hline TM tactics appropriate & 24.33 & 22 & 1.14 & NS \\
\hline Control loss & 37.89 & 22 & 1.51 & NS \\
\hline \multicolumn{5}{|l|}{ Project size } \\
\hline PM tactics & 49.80 & 48 & 1.03 & NS \\
\hline TM tactics use & 58.36 & 48 & 0.78 & NS \\
\hline TM tactics appropriate & 43.39 & 48 & 0.85 & NS \\
\hline Control loss & 58.47 & 48 & 0.84 & NS \\
\hline \multicolumn{5}{|l|}{ Organization size } \\
\hline PM tactics & 69.60 & 60 & 1.36 & NS \\
\hline TM tactics use & 83.41 & 60 & 0.979 & NS \\
\hline TM tactics appropriate & 68.66 & 60 & 1.40 & NS \\
\hline Control loss & 82.36 & 60 & 1.04 & NS \\
\hline \multicolumn{5}{|l|}{ Project complexity } \\
\hline PM tactics & 29.58 & 23 & 1.33 & NS \\
\hline TM tactics use & 32.67 & 23 & 1.01 & NS \\
\hline TM tactics appropriate & 23.42 & 23 & 1.03 & NS \\
\hline Control loss & 41.26 & 23 & 1.74 & NS \\
\hline \multicolumn{5}{|l|}{ Interpersonal trust } \\
\hline PM tactics & 25.22 & 15 & 1.49 & NS \\
\hline TM tactics use & 29.92 & 15 & 1.52 & NS \\
\hline TM tactics appropriate & 20.18 & 15 & 1.43 & NS \\
\hline Control loss & 27.92 & 15 & 1.46 & NS \\
\hline
\end{tabular}




\section{Appendix D: Measurement Items}

Table D1. Control Loss Model Fit and Factor Loadings

\begin{tabular}{lc}
\hline Chi-square/df & 1.38 \\
CFI & 0.959 \\
RMSEA & 0.048 \\
Reliability (rho) & 0.968 \\
Items & Loadings \\
\hline PMCLP1 & 0.757 \\
PMCLP2 & 0.870 \\
PMCLP3 & 0.734 \\
PMCLP4 & 0.832 \\
PMCLP5 & 0.848 \\
PMCLP6 & 0.805 \\
PMCLPR1 & 0.692 \\
PMCLPR2 & 0.718 \\
PMCLPR3 & 0.784 \\
PMCLPR4 & 0.777 \\
PMCLPR5 & 0.698 \\
PMCLPR6 & 0.750 \\
PMCLRE1 & 0.825 \\
PMCLRE2 & 0.723 \\
PMCLRE3 & 0.716 \\
PMCLRE4 & 0.890 \\
PMCLRE5 & 0.884 \\
PMCLRE6 & 0.825 \\
PMCLRE7 & 0.823 \\
PMCLRE8 & 0.846 \\
\hline Notes: PMCLP = project manager response to control loss with respect to people; PMCLPR = project \\
manager response to control loss with respect to process; PMCLRE = project manager response to \\
control loss with respect to resources. & \\
\hline
\end{tabular}


Table D2. Control Loss and Project Performance Factor Loadings

\begin{tabular}{lcc} 
Factors & 1 & 2 \\
\hline PMCLP1 & $\mathbf{0 . 7 5 4}$ & -0.094 \\
PMCLP2 & $\mathbf{0 . 8 5 6}$ & -0.158 \\
PMCLP3 & $\mathbf{0 . 7 3 7}$ & -0.056 \\
PMCLP4 & $\mathbf{0 . 8 3 2}$ & -0.078 \\
PMCLP5 & $\mathbf{0 . 8 3 1}$ & -0.176 \\
PMCLP6 & $\mathbf{0 . 8 0 2}$ & -0.098 \\
PMCLPR1 & $\mathbf{0 . 6 8 6}$ & -0.100 \\
PMCLPR2 & $\mathbf{0 . 7 3 1}$ & 0.010 \\
PMCLPR3 & $\mathbf{0 . 7 8 6}$ & -0.063 \\
PMCLPR4 & $\mathbf{0 . 7 6 3}$ & -0.143 \\
PMCLPR5 & $\mathbf{0 . 6 7 8}$ & -0.169 \\
PMCLPR6 & $\mathbf{0 . 7 4 5}$ & -0.092 \\
PMCLRE1 & $\mathbf{0 . 8 1 2}$ & -0.140 \\
PMCLRE2 & $\mathbf{0 . 7 2 0}$ & -0.075 \\
PMCLRE3 & $\mathbf{0 . 7 0 1}$ & -0.142 \\
PMCLRE4 & $\mathbf{0 . 8 7 7}$ & -0.144 \\
PMCLRE5 & $\mathbf{0 . 8 6 5}$ & -0.183 \\
PMCLRE6 & $\mathbf{0 . 7 9 7}$ & -0.222 \\
PMCLRE7 & $\mathbf{0 . 8 0 8}$ & -0.145 \\
PMCLRE8 & $\mathbf{0 . 8 2 2}$ & -0.200 \\
PMPP1 & -0.134 & $\mathbf{0 . 8 3 4}$ \\
PMPP2 & -0.040 & $\mathbf{0 . 7 9 3}$ \\
PMPP3 & -0.127 & $\mathbf{0 . 8 7 0}$ \\
PMPP4 & -0.124 & $\mathbf{0 . 8 8 6}$ \\
PMPP5 & -0.178 & $\mathbf{0 . 9 0 6}$ \\
PMPP6 & -0.179 & $\mathbf{0 . 8 3 4}$
\end{tabular}

Notes: PMCLP = project manager response to control loss with respect to people; PMCLPR = project manager response to control loss with respect to process; PMCLRE $=$ project manager response to control loss with respect to resources; PMPP = project manager response to project performance. Boldface figures indicate the factor loadings of the construct.

Table D3. Control Loss and Project Performance

\begin{tabular}{llccc} 
& $\begin{array}{c}\text { Control } \\
\text { loss }\end{array}$ & $R^{2}$ & Adjusted $R^{2}$ & $F$ \\
\hline $\begin{array}{l}\text { Project } \\
\text { performance }\end{array}$ & $-0.241^{*}$ & 0.381 & 0.364 & $22.343^{\star * *}$ \\
\hline$+p<0.1 ; * p<0.05 ; * * p<0.01 ; * * * p<0.001$. & & \\
\hline
\end{tabular}


Table D4. Influence Tactics Model Fit Statistics and Factor Loadings

\begin{tabular}{|c|c|c|c|c|}
\hline Chi-square & & 733 & 696 & 523 \\
\hline CFI & & 0.921 & 0.972 & 0.971 \\
\hline RMSEA & & 0.052 & 0.05 & 0.05 \\
\hline Reliability (rho) & & 0.973 & 0.987 & 0.979 \\
\hline Influence tactic & Items & PM & $\begin{array}{c}\text { TM } \\
\text { (use scale) }\end{array}$ & $\begin{array}{c}\mathrm{TM} \\
\text { (appropriateness } \\
\text { scale) } \\
\end{array}$ \\
\hline \multirow{4}{*}{$\begin{array}{l}\text { Rational } \\
\text { persuasion }\end{array}$} & RP1 & 0.872 & 0.954 & 0.828 \\
\hline & RP2 & 0.930 & 0.974 & 0.895 \\
\hline & RP3 & 0.787 & 0.949 & 0.857 \\
\hline & RP4 & 0.780 & 0.943 & 0.884 \\
\hline \multirow{4}{*}{$\begin{array}{l}\text { Inspirational } \\
\text { appeal }\end{array}$} & $\mathrm{A} 1$ & 0.909 & 0.907 & 0.885 \\
\hline & A2 & 0.905 & 0.915 & 0.804 \\
\hline & A3 & 0.944 & 0.970 & 0.923 \\
\hline & A4 & 0.792 & 0.920 & 0.864 \\
\hline \multirow[t]{4}{*}{ Legitimating } & L1 & 0.893 & 0.916 & 0.903 \\
\hline & L2 & 0.843 & 0.916 & 0.902 \\
\hline & L3 & 0.890 & 0.927 & 0.929 \\
\hline & L4 & 0.741 & 0.903 & 0.840 \\
\hline \multirow[t]{4}{*}{ Pressure } & PR1 & 0.665 & 0.866 & 0.818 \\
\hline & PR2 & 0.576 & 0.838 & 0.770 \\
\hline & PR3 & 0.790 & 0.928 & 0.894 \\
\hline & $\mathrm{PR} 4$ & 0.638 & 0.881 & 0.816 \\
\hline \multirow[t]{4}{*}{ Collaboration } & CL1 & 0.795 & 0.960 & 0.930 \\
\hline & CL2 & 0.831 & 0.906 & 0.921 \\
\hline & CL3 & 0.771 & 0.960 & 0.943 \\
\hline & CL4 & 0.835 & 0.941 & 0.954 \\
\hline \multirow[t]{4}{*}{ Consultation } & $\mathrm{CN} 1$ & 0.955 & 0.980 & 0.986 \\
\hline & $\mathrm{CN} 2$ & 0.947 & 0.986 & 0.973 \\
\hline & CN3 & 0.954 & 0.973 & 0.972 \\
\hline & $\mathrm{CN} 4$ & 0.942 & 0.961 & 0.959 \\
\hline \multirow[t]{4}{*}{ Coalition } & CA1 & 0.796 & 0.956 & 0.964 \\
\hline & CA2 & 0.770 & 0.957 & 0.941 \\
\hline & САЗ & 0.822 & 0.904 & 0.913 \\
\hline & CA4 & 0.819 & 0.944 & 0.928 \\
\hline
\end{tabular}

Post-print standardized by MSL Academic Endeavors, the imprint of the Michael Schwartz Library at Cleveland State University, 2014 